\title{
Nutrition security, livelihoods and HIV/AIDS: implications for research among farm worker households in South Africa
}

\author{
S Lemke* \\ Centre for International Development and Environmental Research, Section Nutrition Security, Justus-Liebig University \\ Giessen, Otto-Behaghel-Strasse 10, D-35394 Giessen, Germany and Visiting Research Fellow, Nutrition \\ Department, Faculty of Health Sciences, North West University, Potchefstroom Campus, Private Bag X6001, \\ Potchefstroom 3520 South Africa
}

\section{Submitted 3 March 2004: Accepted 23 March 2005}

\begin{abstract}
Objective: Previous research on the health transition and nutrition security in black South African households revealed the need for further research among farm workers who belong to the poorest population categories. This article gives an overview of the link between nutrition security, livelihoods and HIV/AIDS in South Africa, drawing conclusions for research among farm worker households.

Design and setting: A literature review, observations on farms and interviews with farmers and key informants were carried out in 2003 and 2004. Peer examination was done with South African and German researchers from the natural and social sciences. Results: Farm workers face poverty and nutrition insecurity and continue to be a tragically underserved population group, also in terms of research. There is furthermore a lack of in-depth research on underlying causes for nutrition security in South Africa and on the link with livelihoods, poverty and HIV/AIDS. Micro-social qualitative research from the household and gender perspective is required, as valid data on households, their internal dynamics and therefore the reflection of social realities are missing. A multidisciplinary research approach based on a new conceptual framework was developed to address the situation of farm worker households.

Conclusion: The outlined research contributes to existing programmes on farms in the North West Province, with the findings being valid also for other parts of southern Africa facing poverty, nutrition insecurity and HIV/AIDS.
\end{abstract}

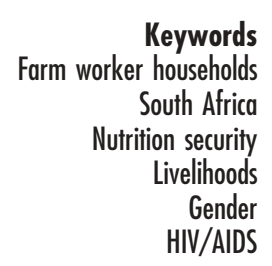

Research on the nutrition security ${ }^{1,2}$ and physical and mental health status ${ }^{3}$ of Setswana-speaking South Africans in the North West Provincet served as initial starting point for the overview and research framework presented herein. Farm worker households $\ddagger$ were found to be among the most vulnerable of all social strata with regard to income, health status, household nutrition security and education. Previous research also revealed that, besides low socio-economic status, underlying social causes have a negative influence on the nutritional situation of schoolchildren ${ }^{4}$. It was concluded that a multidisciplinary research approach is needed to investigate underlying social causes for nutrition insecurity further. This information is crucial for sustainable social development. Projects have failed in the past due to a lack of

tThe largest population group in the North West Province are the Tswana people, who mainly speak Setswana.

$\ddagger$ Farm worker households or farm dwellers refer to dependant wage labourers and their families who work or live on mostly white-owned farms. 'Farm' refers both to commercial farms and also to smallholdings where farm owners perform small-scale farming as an additional income. The term 'farm household' is used for reasons of simplicity instead of 'farm worker household'. baseline information and due to a lack of understanding of complex processes rooted in the past and continuing into the present. Moreover, in the light of rapid social transformation and sensitive political processes currently taking place in South Africa regarding land restitution and minimum wages, and with criminal attacks on residents of commercial farms being very prevalent, conditions and circumstances on farms urgently need to be addressed. This paper aims at giving an overview on nutrition security in South Africa and its link with poverty, livelihoods and HIV/AIDS, and draws conclusions for research in the specific setting of farm worker households.

\section{Design and setting}

Research was carried out in collaboration with the Nutrition Research Group at North West University, Potchefstroom, South Africa, which initiated a larger research and intervention programme on farms in the North West Province $^{4}$, as a follow-up of previous research ${ }^{3}$.

For the research presented here, farms in the Potchefstroom and Ventersdorp Districts, North West Province, 
were visited in April and from August to October 2003, doing observations and interviews with farmers and key informants. A literature review was done on the concepts investigated. For the purpose of peer examination ${ }^{5}$, discussions were held with academics from the disciplines of Nutrition Sciences, Social Anthropology, Sociology, Development Studies and Community Development from different universities and research institutions in South Africa and Germany. The research approach was further presented at the annual conference Anthropology Southern Africa, August $2003^{6}$, and feedback received.

\section{Nutrition insecurity, poverty and HIV/AIDS in South Africa}

Poverty, nutrition insecurity* and HIV/AIDS are among the most pressing social issues in South Africa and Sub-Saharan Africa. About half of the South African population is foodinsecure $^{7}$ and categorised as being poor ${ }^{8}$. The distribution of income is highly skewed. In no other country in southern Africa are substantial differences with regard to income more striking? The rapid transition taking place in South Africa causes problems of adaptation mainly for the poor regarding their often deteriorating socio-economic conditions ${ }^{7}$. While widely held public opinion still associates hunger mainly with emergencies, conflict and calamities, greater awareness needs to be created of the chronic dimensions of food insecurity, its multiple negative effects and its links with poverty $^{10}$. As national ${ }^{11}$ and local ${ }^{12}$ surveys in South Africa indicate, there are low levels of acute undernutrition (i.e. wasting), but high levels of chronic undernutrition and malnutrition, manifested as stunting, reflecting chronic exposure to adverse conditions. South Africa is also among the countries with the highest prevalence of HIV/AIDS, with about $20 \%$ of the adult population being infected ${ }^{13}$, which further threatens social and economic development and nutrition security. According to the Food and Agriculture Organization of the United Nations $(\mathrm{FAO})^{14}$, in South Africa the projected loss in the agricultural labour force through AIDS from 1985 to 2020 will be 20\%, making South Africa one of the nine hardest hit countries in the world.

According to the widely used definition of $\mathrm{FAO}^{15}$, 'Food security exists when all people, at all times, have physical and economic access to sufficient, safe and nutritious food to meet their dietary needs and food preferences for an active and healthy life'. The term food security was later enlarged to nutrition security or food and nutrition security, as this more accurately reflects the complexity of nutrition problems, beyond food supply and access to food, considering decisive factors such as health issues and care for women and children ${ }^{16}$. It furthermore has to be taken into account that food and nutrition security is not just about the absence of hunger, but also about the absence of risk

*The terms 'nutrition security/insecurity' are used alternately in this article. relating to adequate food consumption. At the 2002 World Food Summit, the commitments made at the 1996 Summit to halve poverty and the number of food-insecure people by 2015 were reaffirmed ${ }^{17}$. The fight against hunger is also one of the Millennium Development Goals that were established in 2000 by 189 nations $^{18}$, among them South Africa.*

While there is a vast amount of literature on food and nutrition security in the southern African region ${ }^{19-22}$, in South Africa, studies on underlying causes of nutrition security are limited. The literature in this field in the past was mainly concerned with food availability at the national level $^{23-25}$ and with health-related issues focusing on immediate causes of nutrition insecurity, nutritional status and under- and malnutrition, without investigating underlying causes ${ }^{26}$. Research on food and nutrition security only started to receive wider recognition during the 1990s, with the emphasis still being on nutritional status ${ }^{27,28}$. In recent years, qualitative ${ }^{29,30}$ and quantitative ${ }^{12,31}$ studies have been conducted in South Africa to identify the food-insecure and risk factors for undernutrition, pointing out the need for complementary research at the local level and the need to investigate underlying complex causes for nutrition insecurity. In South Africa, as well as in other southern African countries $^{32}$, food and nutrition security is largely a social and also a political problem, as is for example currently experienced in Zimbabwe. In South Africa, to date the issue has mainly been addressed by agricultural economists, physicians and nutritionists. A social perspective is urgently needed to shed light on underlying problems at the individual, household and community level.

\section{The link between nutrition security, livelihoods, gender relations and HIV/AIDS}

In the so-called third wave of the AIDS pandemic that has just started in South Africa, mortality rates are outstripping new infections and South Africa is entering the 'death' phase, a part of the cycle that threatens both the healthcare system and the economy ${ }^{33}$. The AIDS pandemic is viewed as a result of pre-existing patterns of sexual culture and gender inequality combined with ongoing labour migration, urbanisation, civil strife, growing poverty and family disintegration ${ }^{34}$. The link between nutrition security, livelihoods and HIV/AIDS and the devastating confluence of AIDS and food scarcity is now widely recognised ${ }^{35-37}+$ AIDS kills the most productive and

*The progress towards the Millennium Development Goals is continuously being monitored. See http://www.undp.org.za/ and http://hdr.undp.org/reports/global/2002/en/pdf/hdr_2002_a_1_3. pdf.

†An international conference on HIV/AIDS, Food and Nutrition Security was held on 14-16 April 2005 in Durban, South Africa, organised by the International Food Policy Research Institute in collaboration with other research institutes and international organisations, among them the World Health Organization, FAO, the Joint United Nations Programme on HIV/AIDS and RENEWAL. 
reproductively active members of society, thus increasing the number of dependant household members and also the number of orphans and child-headed households ${ }^{38}$, leading to a vicious cycle linking poverty, food insecurity and HIV/AIDS to each other ${ }^{13,39}$. The nutritional aspect of HIV/AIDS that has been ignored for a long time is now acknowledged, and good nutrition is regarded as one of the few bulwarks against AIDS-related illnesses and early death. Yet, this completely is out of reach for many poor people $^{40}$. HIV/AIDS is not skewed to those households infected and affected, but is systemic and thus affects the social and economic ties upon which communities are built $^{41}$. In Sub-Saharan Africa, women are disproportionately affected by HIV/AIDS and account for 58\% of HIV infections ${ }^{13}$. The main reason why they are more vulnerable than men is gender inequality and women's social, cultural, economic and biological vulnerability ${ }^{42,43}$. Men, due to migrant work and patriarchal ideals, often pursue multiple relationships, which increases the risk for women to be infected with HIV. As women at the same time carry the main burden of HIV/AIDS in caring for the sick and for orphaned children, and as they play a key role for achieving nutrition security and fighting poverty ${ }^{44,45}$, this situation leads into another vicious cycle and further weakens existent social support networks. As is stated in Article 14 of the Declaration of Commitment on HIV/AIDS of the United Nations ${ }^{36}$ and has been transferred into action by the formation of The Global Coalition on Women and AIDS on 2 February $2004^{46}$, gender equality and the empowerment of women are fundamental elements in the reduction of the vulnerability of women and girls to HIV/ AIDS. This very clearly stresses the need for a comprehensive gendered perspective.

Gender relations play an important role in the general well-being of members of South African households, especially for women and children. Male dominance is still very prevalent in the majority of conjugal relationships and there are high levels of conflict within households, mainly about income and other resources ${ }^{47-50}$, impacting on household nutrition security. The alarmingly high incidence of violence against women is seen as a result of a patriarchal society ${ }^{51}$ and has been described as the "crisis of African masculinity" ${ }^{52}$. A trend that had been noted by several authors in South Africa already in the $1960 \mathrm{~s}^{53}$ is that women increasingly prefer to stay single rather than to live with a male partner whom they often regard as an economic liability ${ }^{49}$, which is reflected in the high percentage of female-headed households that reaches up to $50 \%$ in South Africa ${ }^{51,54}$. While this high percentage is partly the result of social forces such as migration, with similar percentages of female-headed households being found in other African countries ${ }^{55}$, it is also the result of choice by women and can therefore partly be regarded as a means of self-empowerment from male dominance. Men, on the other hand, are often not able to marry due to economic constraints, this often being the result of unemployment, and due to the requirement of paying marriage goods. Gender relations therefore directly influence household composition, the socio-economic situation and the characteristics of poverty.

\section{The specific situation of South African farm workers}

While in South Africa the association between poverty and unemployment is widely recognised, it is less frequently realised that low pay and poverty are widespread also among those who are formally employed. South African farm workers are the most vulnerable members of the South African work force, earning the lowest wages, ${ }^{*}$ with women earning even less than men ${ }^{56}$. Agriculture provides about $11 \%$ of South Africa's formal employment $^{57}$ and $27 \%$ of informal employment ${ }^{58}$, thereby constituting an important economic sector. Although the government introduced minimum wages for farm workers in 2003 to improve their economic situation ${ }^{59}, t$ in practice this sometimes means that farmers cut previous benefits such as housing subsidies and food portions, leaving farm workers with even less than before. $\neq$ The introduction of minimum wages in some cases also led to higher unemployment $^{60}$.

The present-day situation of people working on farms has to be seen in the context of South African history. Unlike in most countries in Sub-Saharan Africa, where households draw on a diverse portfolio of activities and income sources that enhance nutrition security, health, social networks and savings and furthermore bridge the rural-urban divide ${ }^{32,61}$, in South Africa, as a result of racial and political inequalities, people were uprooted long ago from the natural resource basis of their livelihoods ${ }^{62-64}, \S$ destroying subsistence farming and contributing to household food insecurity. The absence of trade union organisation and limited means of legal protection from human rights violations and work-related abuses ${ }^{66,67}$ resulted in farm workers and their families being 'trapped' on farms, lacking the skills to engage in the wider economy and having no possibilities of advancement. Studies focusing on the health status of farm workers ${ }^{68,69}$ stress that they continue to represent a seriously and tragically underserved worker population whose health is

*The average cash wage in agriculture in 2000 was R544 (€68.00) per month, which was far below the household Minimum Living Level of R970 (€121.25) per month.

†A minimum wage for farm workers was implemented on 1 March 2003 and currently amounts to R785.80 (€100.74) or R949.60 (€121.74), respectively, depending on the municipality the farm belongs to (exchange rate 13 March 2005; http://www.x-rates.com/d/ ZAR/table.html).

‡This was elaborated by farm workers in informal conversations during farm visits in 2003 and also by key informants.

$\S$ The concept of 'sustainable livelihoods' has become increasingly central to the international debate about development, poverty reduction and environmental management in recent years ${ }^{65}$. 
adversely affected by occupational hazards in agriculture, migrancy, social discrimination and poverty. These studies also point out high levels of alcohol abuse, domestic violence and chronic malnutrition. Children living on commercial farms are more likely to be stunted and underweight than any other children, with only one child in four being food-secure ${ }^{3}$.

While some farmers, as well as the larger public and even some academics perceive farm workers as having no self-restraint or willpower and being 'lazy', a number of farmers point out the difficult situation of farm workers and the necessity to improve their situation, ${ }^{*}$ however often not having the resources or not knowing how this could be achieved. During the current process of land restitution in favour of previously discriminated and marginalised population groups, and consequent legal uncertainty and expectations attached to land ownership, farms are sources of conflict and increasing poverty ${ }^{61,70}$, thus also increasing the vulnerability to nutrition security and consequently high-risk behaviour with regard to HIV/ AIDS. The issue of land is furthermore very emotive, as is experienced in the example of neighbouring Zimbabwe where so-called 'land restitution' has been made a central political issue by the government ${ }^{71}$. White South African farmers fear that similar processes could take place also in their country ${ }^{72}$. Another serious problem is criminal attacks on (mainly white) residents of farms and smallholdings that have been escalating at a rate disproportionate to the general increase in crime figures prevalent in South Africa ${ }^{73}$.

\section{The concept of 'household' - complex social realities}

In South Africa, discriminatory political practices and the resultant increase in migrant labour led to the disruption of households and functioning social systems. The bad effects this had on family life have been described by numerous authors $^{74-77}$. A variety of household categories emerged as a social response. $\dagger$ Factors that are nowadays compounding the disruption and disorganisation of households and community life ${ }^{47}$ and the maintenance of the migrant labour system, among them high or endemic unemployment, poverty and the devastating effect of HIV/AIDS ${ }^{79}$, have been highlighted in earlier sections.

The household is a fundamental social unit and a standard unit of analysis in censuses. In the economic

*These views were expressed to the author and other collaborators in this project during 2003 and 2004.

tAlso in Europe and especially Germany, similar household forms to those revealed in South Africa existed during and after World War II. With men being absent at war or imprisoned, women had to cope with extreme poverty and had to find other support networks. When the economic situation improved, nuclear household units were reestablished $^{78}$. analysis of food security the assumption still persists that households consist of members with a single economic aim, complementary objectives and tied to the same social networks within a shared social environment ${ }^{32,80}$. Also, poverty estimates based on household surveys still assume that household resources are equally shared ${ }^{81}$. This assumption is especially misleading in low-income households. A number of authors ${ }^{82-84}$ argue that using the household as a homogeneous unit creates oversimplification. In addition, the perception of the household as a co-residential unit, as it is still defined in national censuses in South Africa ${ }^{85}$, is an inadequate unit of analysis if one wishes to explore social and economic processes. Moreover, the concept of 'head of household' in contemporary South Africa attributes headship in general to men and makes it therefore difficult to determine the number and the composition of households actually headed by women ${ }^{86}$. This male-biased classification of headship further gives no indication of the true dynamics within households that are fundamentally significant for the well-being of their members. Experts emphasise the need to give more attention to gender-disaggregated data collection, detailed context-specific research, and comparative empirical research to avoid making simplistic correlations ${ }^{81}$. Data collection methods are therefore required that capture some of the complexities of South African households, such as the fluidity of household composition, high levels of individual and household mobility, non-resident household members and multiple household memberships ${ }^{85}$, and, in the specific context of farms, categories of permanent and temporary workers ${ }^{87}$.

As has been highlighted in this section, in the specific South African context conventional Western concepts of the household do not apply, neither do models of farm households as existent in other African countries ${ }^{88}$ nor the concept of 'multiple group membership' that can be found among subsistence cultures ${ }^{89}$. However, certain characteristics of the household do apply in both Western and African societies, which will be illustrated in the following section.

\section{Conclusions for research leading to a new conceptual framework}

The following conclusions for research evolve from the overview of the literature:

1. There is a lack of qualitative in-depth research on underlying causes of nutrition insecurity and its link with livelihoods and HIV/AIDS. As has been pointed out, these issues are all interrelated and should therefore be investigated in close association to one another, applying a social sciences research approach.

2. There is furthermore a lack of research on farm worker households. With regard to their poor economic and 
social situation, and also with regard to the current tense political situation, the situation of farm workers urgently has to be addressed.

3. The need for a household and gender perspective in the context of nutrition security is emphasised, in order to trace the causal relationships between intra-household dynamics and the well-being of households and its members, providing insights into the social realities of people.

Based on these conclusions, a new conceptual framework and multidisciplinary research project were developed, integrating the disciplines of Nutrition Sciences, Social Anthropology, Sociology, Economics, Geography, Agriculture and History. The new conceptual research framework* (Fig. 1) draws on elements of the UNICEF (United Nations Children's Fund) framework ${ }^{90}$ and the household system-logic based on the conceptualisation of Von Schweitzer ${ }^{91}$, which is founded on a social systems approach and is historically a progression of the philosophical theme that the whole is more than the sum of its parts or elements. $t$

In the centre of the framework is the bousebold triangle, which represents the basis for all actions at the household level, consisting of activities that are influenced by attitudes towards life in general, livelihood assets or resources and capabilities. It is assumed that in South Africa, the household is still the prime locus for bonds which are enduring and basic whether or not individual household members are present or temporarily absent, as is the case for labour migrants. However, the household is no homogeneous economic unit, but conflict and competition over resources are usually endemic, with household members having different objectives and being connected to different external social networks. It is therefore crucial to uncover the relevant elements of this framework, their relationships, the intensity of interactions and the differences of power and control between individual household members, which are influenced by gender relations and other intra-household dynamics, as highlighted in the centre of the triangle. The different existing household categories that can comprise the triangle, e.g. conjugal households (male-headed/jointly headed) or female-headed households (de facto/de jure female-headed), which can consist of migrant households, pensioner households, sibling households, etc., reflect

*This framework is preliminary and will be subject to further development during the progress of research.

†For a detailed description of the household system-logic, the reader is referred to Von Schweitzer ${ }^{91}$, whose original work on which this theory is based ${ }^{92}$ is currently in the process of being translated into English. For the purpose of this paper, using the household triangle shall suffice to illustrate relationships and dynamics within the household and its micro-environment and to highlight links and interdependences with the meso-environment, representing underlying causes for nutrition insecurity. different stages during the life cycle. As has been described earlier, South African households are characterised by fluid boundaries and are often stretched over several domestic units, resulting in multiple household membership. As illustrated in Fig. 1, multiple household membership is represented by $\mathrm{H} 1$ - the core household that is being observed - and by $\mathrm{H} 2$ and $\mathrm{H} 3$ and possibly also $\mathrm{H} 4, \mathrm{H} 5$, etc., representing extended households that are connected to H1 through kinship or other social relationships. To categorise households, taking into account these complexities, a previously developed concept ${ }^{1}$ is used here, defining the household as all people who share income and other resources and/or certain obligations and interests, whether they belong to the same or different residential units. In most cases, members of these bousebolds are related by kinship links. The specific social structure surrounding households includes social networks, such as neighbourhood relationships, relationships with local shop owners, savings associations or other mostly female - networks. Some of these networks are situated at the community level, with the term 'community' having to be investigated carefully, as communities are not undifferentiated and co-operative social groups, as is often assumed. Of central importance are furthermore the relationships between farm workers and the farm owner, as living conditions of farm workers often depend on the wealth and/or on the goodwill of the farmer, which also partly determines what infrastructure is in place.

As is illustrated in the framework, the bousebold triangle represents at the same time the nutrition security system, as activities, livelihood assets, capabilities and the dynamics within this system, which were referred to above, influence household nutrition security. When investigating the nutrition security system at the individual level, it becomes obvious that it is even more differentiated, depending not only on household dynamics, but also on individual activities, assets and capabilities and access of individual household members to social networks and sources of food.

The determinants for nutrition insecurity are placed on different causality levels, represented by the surrounding circles, using a less hierarchical structure than the UNICEF framework $^{90}$. Basic causes relate to the macro-environment, underlying causes relate to the meso-environment and immediate causes (such as diseases and dietary intake, which are not illustrated in this framework but are recognised in this research) relate to the micro-environment. These underlying causes for nutrition security interact in a mutually reinforcing manner and also interact with the nutrition security system within the household triangle. This is illustrated using the incidence of HIV/AIDS as an example. The impact of HIV/AIDS is made much worse by the malnourished state of a person (immediate cause, relating to micro-environment) and also by a lack of health services and medical treatment (underlying cause, relating to meso-environment). On the other hand, 


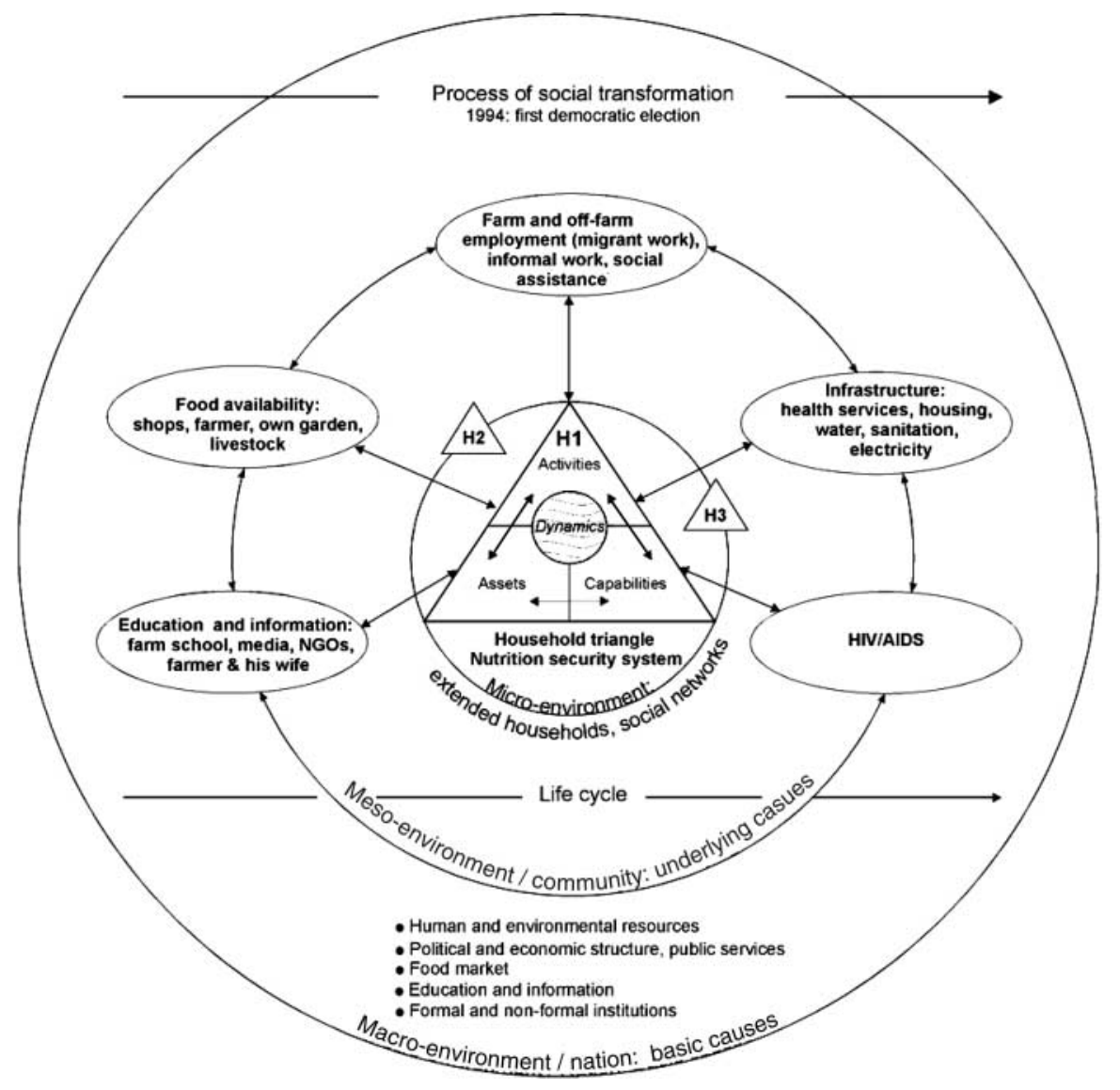

Fig. 1 Nutrition security and underlying causes from the perspective of black South African farm worker households. H1 - household that is being observed; H2, H3 - extended households, connected through kinship or other social relationships; NGO - non-governmental organisation

a malnourished person is more vulnerable to contract diseases and to develop AIDS (again relating to the meso-environment: e.g. prevalence of HIV/AIDS in the community, as well as prevalence of other diseases; exposure to diseases, including HIV/AIDS, which is often being transmitted by migrant workers), which is often accompanied by a loss of appetite that can lead to further deterioration of health status. If an adult household member becomes ill, this results in loss of employment and income, while additional time and financial resources are needed to care for the sick person, therefore further degrading the already marginal resources (affecting both the micro- and meso-environment). People who are hungry might be forced to employ dangerous survival strategies to acquire food, such as getting involved in criminal activities, selling sex or pursuing multiple sexual relationships to secure resources, which increases the risk of contracting HIV (relating to the meso-environment: e.g. level of crime in the community or surrounding areas; prevalence of HIV/AIDS in the community; exposure to other sexually transmitted diseases; incidence of rape). Labour migrancy (relating both to the meso- and macroenvironment) that on the one hand secures resources for the households, at the same time increases the risk for HIV infection. The macro-environment determines the perception of HIV/AIDS at the political level - which still is regarded as highly controversial in South Africa $^{93}$ impacting on medical treatment, on the dissemination of information and education (meso-environment) and also on subjective perceptions of AIDS (micro-environment).

\section{Conclusion and outlook}

The results of this research will provide baseline knowledge and a better understanding of the underlying causes for nutrition insecurity and its link with poverty, livelihoods and HIV/AIDS, contributing to existing community initiatives on farms in the North West Province. The findings will be valid not only for the South African context, but by addressing issues that are entailed in the Millennium Development Goals also for other societies that are experiencing similar problems and where the gap between rich and poor is currently widening. The findings will furthermore uncover household dynamics and gender differences in the context of poverty, which is an essential condition for better targeting of development 
programmes. The success and sustainability of such programmes is of utmost importance, especially in South Africa, as it plays a key role for the economic, social and political development of the whole region.

\section{Acknowledgements}

The comments of a number of academic peers during the development of this project, as well as on earlier drafts of this article, are greatly acknowledged, especially the following: Professor I-U Leonhaeuser (also for financial support in 2003) and colleagues at the Centre for International Development and Environmental Research and at the Department of Sociology, Justus-Liebig University Giessen, Germany; Professor HH Vorster and Dr A Kruger (also for logistical support), School of Physiology, Nutrition and Consumer Sciences, Faculty of Health Sciences and Dr NS Jansen van Rensburg, Social Anthropology, School of Social and Government Studies, all of North West University, Potchefstroom Campus, South Africa; Professor T de Wet and C van Rooyen, Department of Anthropology and Development Studies, University of Johannesburg, South Africa; Professor Emeritus J Ziche, formerly Department of Rural Sociology, Centre of Life Sciences, Technical University of Munich, Germany. The comments of two anonymous reviewers are also acknowledged. This research is funded by the German Research Council (Deutsche Forschungsgemeinschaft) and co-funded to do related application-oriented research by the Belgiam nongovernmental organisation Nutrition Third World and the National Research Foundation, South Africa.

\section{References}

1 Lemke S. Food and nutrition security in black South African households - creative ways of coping and survival. Dissertation, Centre of Life Sciences Weihenstephan, Technical University of Munich, Germany, 2001. Available at http://tumb1.biblio.tumuenchen.de/publ/diss/ww/2001/ lemke.pdf

2 Lemke S, Jansen van Rensburg NS, Vorster HH, Ziche J. Empowered women, social networks and the contribution of qualitative research: broadening our understanding of underlying causes for food and nutrition insecurity. Public Health Nutrition 2003; 6(8): 759-64.

3 Vorster HH, Wissing MP, Venter CS, Kruger HS, Kruger A, Malan NT, et al. The impact of urbanization on physical, physiological and mental health of Africans in the North West Province of South Africa: The THUSA Study. South African Journal of Science 2000; 96: 1-10.

4 Phometsi M, van't Riet H, Kruger A. Nutrition knowledge and barriers to dietary practices among school children in a farming community - FLAGH-programme. Development Southern Africa 2005; in press.

5 Creswell JW. Research Design. Qualitative and Quantitative Approaches. Thousand Oaks, CA: Sage, 1994.

6 Lemke S, Jansen van Rensburg NS. Black farm households in the North West Province, South Africa - evidence on household organisation, nutrition security and social relations and implications for further research. Paper presented at the annual conference Anthropology Southern Africa, University of Cape Town, South Africa, 24-27 August 2003.

7 Parikh KS. World food system: resilient for the rich, stubborn for the starving. SCN News/United Nations, Administrative Committee on Coordination, Sub-Committee on Nutrition 2000; 20: $17-20$.

8 May J, Woolard I, Klasen S. The nature and measurement of poverty and inequality. In: May J, ed. Poverty and Inequality in South Africa: Meeting the Challenge. Cape Town: David Philip, 2000; 19-48.

9 Haddad L, ed. Achieving Food Security in Southern Africa. Washington, DC: International Food Policy Research Institute, 1997.

10 De Haen H. Preparing for the World Food Summit: five years later. In: Civil Society and the UN System: Debate in the Food Security Arena [special issue]. SCN News/United Nations, Administrative Committee on Coordination, Subcommittee on Nutrition 2001; 23: 4-5.

11 Labadarios D, ed. The National Food Consumption Survey (NFCS): Children aged 1-9 years, South Africa, 1999. Technical Report. Pretoria: Department of Health, 2000. Also available at http://www.sahealthinfo.org/nutrition/ foodconsumption.htm

12 Chopra M. Risk factors for undernutrition of young children in a rural area of South Africa. Public Health Nutrition 2003; 6(7): 645-52.

13 Joint United Nations Programme on HIV/AIDS (UNAIDS)/ World Health Organization (WHO). AIDS Epidemic Update, December 2002. Geneva: UNAIDS/WHO, 2002. Also available at http://www.unaids.org

14 Food and Agriculture Organization. HIV/AIDS, Food Security and Rural Livelihoods [online], 2003. Available at http:// www.fao.org/worldfoodsummit/english/fsheet/aids.pdf. Accessed February 2003.

15 Food and Agriculture Organization (FAO). Rome Declaration on World Food Security and World Food Summit Plan of Action. Rome: FAO, 1996; 7.

16 Kracht U, Schulz M, eds. Food Security and Nutrition. The Global Challenge. New York: St. Martin's, 1999.

17 Food and Agriculture Organization (FAO). Declaration of the World Food Summit: Five Years Later [online], 2003. Available at http://www.fao.org. Accessed February 2003.

18 Bread for the World Institute. The Millennium Development Goals [online], 2000. Available at http://www.bread. org/insti.../millennium_challenge_account/goals.htm. Accessed June 2003.

19 Hutchinson B, Frankenberger TR. A selected annotated bibliography on indicators with application to household food security. In: Maxwell S, Frankenberger TR, eds. Household Food Security: Concepts, Indicators, Measurements. A Technical Review. New York: UNICEF, 1992; 193-274.

20 Geldenhuys Z, ed. Food Security in Southern Africa 1974 1994. A Selected and Annotated Bibliography. Bibliographical Series No. 27. Johannesburg: South African Institute of International Affairs, 1994.

21 Laier JK, Davies S, Milward K, Kennen J. Gender, Household Food Security and Coping Strategies: An Annotated Bibliography. Brighton, UK: Institute of Development Studies, University of Sussex, 1996.

22 Van Liere MJ, Kusin JA, Eilander A. Annotated Bibliography on Household Food and Nutrition Security. Amsterdam: Royal Tropical Institute, 2001. Also available at http://www. kit.nl/health/html/fs_bibliography.asp

23 Van Zyl J, Kirsten J. Food security in South Africa. Agrekon 1992; 31(4): 170-84.

24 Van Rooyen CJ, Ngqangweni S, Frost D. Some considerations for a South African food policy. Agrekon 1996; 35(4): $301-8$. 
25 Land and Agriculture Policy Centre. Food Security and Staple Foods: Policy Issues for South Africa. Policy Paper 4. Johannesburg: Land and Agriculture Policy Centre, 1994.

26 Vorster HH, Oosthuizen W, Jerling JC, Veldman FJ, Burger HM. The Nutritional Status of South Africans. A Review of the Literature from 1975-1996. Durban: Health Systems Trust, 1997.

27 Kuzwayo P. Household food security. Welfare Focus 1994; 29: $19-24$.

28 Steyn NP. Nutrition insecurity - a complex problem. South African Medical Journal 1998; 88(5): 639-40.

29 Coutsoudis A, Maunder E, Ross F, Ntuli S, Taylor M, Marcus $\mathrm{T}$, et al. A qualitative study on food security and caring patterns of vulnerable young children in South Africa. WHO Multicountry Study on Improving Household Food and Nutrition Security for the Vulnerable. World Health Organization, Nutrition for Health and Development, Sustainable Development and Healthy Environments, 2000.

30 Maunder E, Gericke G, Labadarios D, Steyn N, MacIntyre U, Huskisson $\mathrm{J}$, et al. The food procurement and household food security of children aged 1-9 years in South Africa: the National Food Consumption Survey, 1999. South African Journal of Clinical Nutrition 2000; 13: 99.

31 Rose D, Charlton KE. Prevalence of household food poverty in South Africa: results from a large, nationally representative survey. Public Health Nutrition 2002; 5(3): 383-9.

32 Mazonde IN. Social transformation and food security in the household: the experience of rural Botswana. In: Krueger F, Rakelmann G, Schierholz P, eds. Botswana. Alltagswelten im Umbruch. Facets of a Changing Society. Hamburg: Lit Verlag, 2000; 53-73.

33 International Food Policy Research Institute (IFPRI). New and noteworthy in nutrition. News Release $\mathbf{4 1}(30$ September). Washington, DC: IFPRI, 2003. Also available at http://www.ifpri.org

34 Leclerc-Madlala S. Youth, HIV/AIDS and the importance of sexual culture and context. In: AIDS and Society [special issue]. Social Dynamics 2002; 28(1): 20-41.

35 International Food Policy Research Institute (IFPRI). New and noteworthy in nutrition. News Release. 39(31 January). Washington, DC: IFPRI, 2003. Also available at http://www. ifpri.org

36 United Nations General Assembly on HIV/AIDS (UNAIDS). Declaration of Commitment on HIV/AIDS [online], Special Session on HIV/AIDS, 25-27 June 2001. Available at http:// www.unaids.org. Accessed June 2003.

37 Gillespie S, Haddad L, Jackson R. HIV/AIDS, food and nutrition security: impact and actions. In: Nutrition and HIV/AIDS. Nutrition Policy Paper No. 20. Geneva: United Nations Administrative Committee on Coordination, Subcommittee on Nutrition, 2001; 31-46.

38 Jackson R, Landis R. The impact of HIV/AIDS on food and nutrition security. Entwicklung und Ländlicher Raum 2002; 36(1): 9-12.

39 Food and Agriculture Organization (FAO). AIDS - a threat to rural Africa. Food insecurity and AIDS: a vicious cycle [online], 2003. Available at http://www.fao.org/FOCUS/E/ aids/aids2-e.htm. Accessed February 2003.

40 Piot P. Nutrition and HIV/AIDS. Keynote address. In: Nutrition and HIV/AIDS. Nutrition Policy Paper No. 20. Geneva: United Nations Administrative Committee on Coordination, Subcommittee on Nutrition, 2001; 7-10.

41 Loevinsohn M, Gillespie S. HIV/AIDS, Food Security and Rural Livelihoods: Understanding and Responding. The Regional Network on HIV/AIDS, Rural Livelihoods, and Food Security (RENEWAL), Working Paper No. 2. Washington, DC/The Hague: International Food Policy Research Institute/International Service for National Agricultural Research, 12 May 2003. Also available at http://www.isnar. cgiar.org/renewal/pdf/RENEWALWP2.pdf
42 Women's Health Research Centre. Violence against women: its importance for HIV/AIDS prevention and care. News and Views 2000; 34(May): 5-8 (Newsletter of the Women's Health Project, University of the Witwatersrand, Johannesburg).

43 Food and Agriculture Organization (FAO). AIDS - a threat to rural Africa. Rural women carry family burdens [online], 2003. Available at http://fao.org.FOCUS/E/aids/aids3-e.htm. Accessed February 2003.

44 International Food Policy Research Institute (IFPRI). Women. The Key to Food Security. Looking into the Household. Washington, DC: IFPRI, 2003. Also available at http://www.ifpri.org

45 Maxwell S, Frankenberger TR, eds. Household Food Security: Concepts, Indicators, Measurements. A Technical Review. New York: UNICEF, 1992.

46 United Nations General Assembly on HIV/AIDS (UNAIDS). The Global Coalition on Women and AIDS. Geneva: UNAIDS, February 2004. Also available at http://www. unaids.org/en/events/coalition.women_and_aids.asp

47 Liebenberg A. Dealing with relationships of inequality. Married women in a Transkei village. In: McAllister PA, ed. Culture and the Commonplace. Johannesburg: Witwatersrand University Press, 1997; 349-73.

48 Spiegel AD, Watson V, Wilkinson P. Domestic diversity and fluidity among some African households in Greater Cape Town. Social Dynamics 1996; 22(1): 7-30.

49 Jones S. Singlehood for security: towards a review of the relative economic status of women and children in womanled households. Society in Transition, Journal of the South African Sociology Association 1999; 30(1): 13-27.

50 Bank L. The social life of paraffin. In: McAllister PA, ed. Culture and the Commonplace. Johannesburg: Witwatersrand University Press, 1997; 157-79.

51 Koen E. Women's empowerment: a threat to the family? Welfare Focus 1994; 29: 13-8.

52 Bank L. Angry men and working women. Gender, violence and economic change in Qwaqwa in the 1980s. African Studies 1994; 53(1): 89-114.

53 Van der Vliet V. Traditional husbands, modern wives? Constructing marriages in a South African township. In: Spiegel AD, McAllister PA, eds. Tradition and Transition in Southern Africa. Johannesburg: Witwatersrand University Press, 1991; 219-41.

54 Niehaus IA. Disharmonious spouses and harmonious siblings: conceptualising household formation among urban residents in Qwaqwa. African Studies 1994; 53(1): 115-35.

55 Schug W. Beiträge der Frauen zur Ernährungssicherung in Entwicklungsländern. Zum Welternährungstag am 16 Oktober 1998. Aid Verbraucherdienst 1998; 43(10): 604-8.

56 National Department of Labour. The Farm Workers Report [online], 2003. Available at http://www.labour.gov.za/docs/ legislation/bcea/Farmdocs/Farmworkers\%20Report.doc. Accessed June 2003.

57 National Department of Labour. Report on Wage Determination, Chapter 4 [online], 2003. Available at http://www. labour.gov.za/docs/policy/fin4.html. Accessed June 2003.

58 Budlender D, Buwembo P, Shabalala N. Composition of employment in the informal economy in South Africa 2000. Excerpts from the 2000 Labour Force Survey, Statistics South Africa. In: Women and Men in the Informal Economy: A Statistical Picture. Geneva: International Labour Office, 2002. Also available at http://www. labour.gov.za/

59 National Department of Labour. Basic Conditions of Employment. Sectoral Determination 8: Farm Workers [online], 2004. Available at http://www.labour.gov.za/ download/6331/Sectoral\%20Determination\%208\%20-\%20 Farm\%20Workers.doc. Accessed March 2005. 
60 National Department of Labour. Agri SA Partners agree to way forward [online], Media Statement, 24 April 2003. Available at http://www.labour.gov.za. Accessed May 2003

61 Murray C, Francis E, Slater R. A risky business: poverty and livelihoods in South Africa. id21 Research Highlight 2001; (9 October). Also available at http://www.id21.org/ society/S1bcm1g1.html

62 Ellis F. Diverse Livelihoods and Natural Resources: A Research Context. Sustainable Livelihoods in Southern Africa: Institutions, Governance and Policy Processes. Sustainable Livelihoods in Southern Africa (SLSA) Working Paper 7. Sussex: SLSA, 2001. Also available at http://www. ids.ac.uk/ids/env/sapubs.html

63 National Department of Agriculture. The History of Agriculture in South Africa [online], 2003. Available at http://www.nda.agric.za. Accessed June 2003.

64 Van Onselen C. The Seed is Mine. The Life of Kas Maine, a South African Sharecropper 1894-1985. New York: Hill and Wang, 1996.

65 Murray C. Livelihoods research: transcending boundaries of time and space. Journal of Southern African Studies 2002; 28(3): 489-509.

66 Southern African Labour and Development Research Unit (SALDRU). Farm labour in South Africa: a review article. Social Dynamics 1976; 2(2): 93-148.

67 Cocks J, Kingwill RA. Land and Agrarian Reform: Transition and Continuity on Former White-Owned Farmland in an Eastern Cape Locality. Grahamstown: Institute of Social and Economic Research, Rhodes University, 1998.

68 Schenker M. The health of farm workers - so much different, so much the same. South African Medical Journal 1998; 88(9): 1091-2.

69 London L, Nell V, Thompson M-L, Myers JE. Health status among farm workers in the Western Cape - collateral evidence from a study of occupational hazards. South African Medical Journal 1998; 88(9): 1096-101.

70 Adams M, Howell J. Reversing land dispossession in Southern Africa. id21 Research Highlight 2002; (10 July). Also available at http://www.id21.org

71 Hartnack A. 'My life got lost': farm workers and displacement in Zimbabwe. Journal of Contemporary African Studies 2005; 23(2): 173-92.

72 Agriculture South Africa (Agri South Africa). Agri SA Leaders Impressions of the Zimbabwean Visit [online], April 2003. Available at http://www.agriinfo.co.za. Accessed May 2003.

73 South African Police Service. Crime Information Analysis Centre, Pretoria [online]. Available at http://www.saps.org. za/8_crimeinfo/farm99/index.htm. Accessed May 2003.

74 Spiegel AD. Migration, urbanisation and domestic fluidity: reviewing some South African sxamples. African Anthropology 1995; II(2): 90-113

75 Van der Waal CS. Rural children and residential instability in the Northern Province of South Africa. Social Dynamics 1996; 22(1): 31-54

76 Ramphele M. A Bed Called Home: Life in Cape Town Hostels. Cape Town: David Philip, 1993.

77 Jones S. Assaulting Childhood: Children's Experiences of Migrancy and Hostel Life in South Africa. Johannesburg: Witwatersrand University Press, 1993.
78 Luescher G. Verwandtschaft, Freundschaft, Nachbarschaft. In Nave-Herz R, Markefa M, eds. Handbuch der Familien- und Jugendforschung. Bd. 1: Familienforschung. Neuwied und Frankfurt-am-Main: Luchterhand, 1989; 435-52.

79 Rugalema G, Khanye V. African rural development in the face of HIV/AIDS. Entwicklung und Ländlicher Raum 2002; 36(1): 7-8.

80 Shah MK. Gendered perceptions of well-being in Darko, Ghana. In: Guijt I, Shah MK, eds. The Myth of Community: Gender Issues in Participatory Development. Paris: OECD, 1998. Also available at http://www1.oecd.org/dac/gender/ pdf/tipsheets/participa.pdf

81 Institute of Development Studies (IDS). Briefing paper on the 'feminisation of poverty'. BRIDGE 2001; 59(April). Brighton, UK: IDS, University of Sussex, 2001. Also available at http://www.ids.ac.uk/bridge/

82 Netting MccR, Wilk RR, eds. Households: Comparative and Historical Studies of the Domestic Group. Berkeley, CA: University of California Press, 1984.

83 Rogers BL, Schlossmann NP, eds. Intra-household Resource Allocation: Issues and Methods for Development Policy and Planning. Tokyo: United Nations University Press, 1990.

84 Pasteur K. Gender Analysis for Sustainable Livelihoods Frameworks, Tools and Links to Other Sources [online], 2002. Available at http://www.livelihoods.org/info/info-toolbox. html. Accessed June 2003.

85 Hosegood V, Timaeus IM. Household composition and dynamics in KwaZulu Natal, South Africa: mirroring social reality in longitudinal data collection. In: Van der Walle E, ed. African Households: Census and Surveys. Illinois: University of Illinois Press, 2005; in press. Paper available as report written on behalf of the Africa Centre Population Studies Group, Africa Centre for Population Studies and Reproductive Health, 2001 (http://www.pop.upenn.edu/africahh/ Hosegood_Timaeus.pdf)

86 Evans A. Statistics. In: Ostergaard L, ed. Gender and Development. London: Routledge, 1992; 11-40.

87 Waldman L, Ntsedi M. Women on highveld farms: an outlook for development. In: Meer S, ed. Women, Land and Authority. Cape Town: David Philip, 1997; 97-110.

88 Netting MccR. Smallholders, Householders: Farm Families and the Ecology of Intensive, Sustainable Agriculture. Stanford, CA: Stanford University Press, 1993.

89 Heywood P. Multiple group membership and intra-household resource allocation. In: Rogers BL, Schlossmann NP, eds. Intra-bousehold Resource Allocation: Issues and Methods for Development Policy and Planning. Tokyo: United Nations University Press, 1990; 135-9.

90 United Nations Children's Fund (UNICEF). Strategy for Improved Nutrition of Children and Women in Developing Countries. A UNICEF Policy Review. New York: UNICEF, 1990.

91 Von Schweitzer R. The personal and social theory of familyhousehold-systems. In: Von Schweitzer R, ed. Cross-cultural Approaches to Home Management. Frankfurt-amMain/New York: Campus, 1993; 101-25.

92 Von Schweitzer R. Einführung in die Wirtschaftslehre des privaten Haushalts. Stuttgart: Eugen Ulmer, 1991.

93 Continuous press coverage in The Weekly Mail E Guardian, Johannesburg. Available at http://www.sn.apc.org 